Folia primat. 1970;12:I-IV

\title{
Contents, Vol. 12, 1970
}

Editor:

J. Biegert, Zurich

Editorial Board:

E. L. Bone, Louvain

W. Fiedler, Wien

H. F. Haklow, Madison, WI

H. Hedigek, Zurich

W. C. Osman Hill, Dublin

H. Hofer, Covington, LA

J. Hürzeler, Basel

J. R. Napier, London

J. Piveteau, Paris

A. Remane, Kiel

A. H. Schultz, Zurich

D. Starck, Frankfurt am Main

W. L. Straus, Jr., Baltimore, MD

S. L. Washburn, San Francisco, CA

H. Zapfe, Wien

S. Zuckerman, Birmingham

$\mathrm{S} 1 / 8 \mathrm{WK}$

S. Karger · Basel (Switzerland) · München · New York

S. Karger AG, Arnold-Böcklin-Strasse 25, CH-4000 Basel 11 (Switzerland)

All rights, including that of translation into other languages, reserved. Photomechanic reproduction (photocopy, microcopy) of this volume or parts thereof without special permission of the publishers is prohibited.

(C) Copyright 1970 by S. Karger AG, Verlag für Medizin und Naturwissenschaften,

Basel

Printed in Switzerland by Schellenberg-Druck, Pfäffikon ZH

Contents

Ahmed, M.: vide Kanagasuntheram, R.

Barfield, M. A.: vide Fitz-Gehald, F. L.

Beard, M. E. J. and Huser, H.-J.: Studies on Folate and Vitamin B12 Meta

bolism in Primates. II. Vitamin B12 Binding Proteins 305

Berkson, G.: Defective Infants in a Feral Monkey Group 284

Bernstein, I. S.: Activity Patterns in Pigtail Monkey Groups 187 
Booth, S. N. and Freedman, L.: Multivariate Discriminant Analysis Applied to Cranial Features of Papio ursinus and P. cynocephalus 296

Capel-Edwards, K. and Hall, D. E.: Haematological Observations on the Squirrel Monkey 142

Chalmers, N. R.: vide Rowell, T. E.

Davenport, R. K.: vide Menzel, E. W., Jr.

Egozcue, J. and Perkins, E. M.: The Chromosomes of Humboldt's Woolly

Monkey (Lagothrix lagotrícha, Humboldt 1812) 77

Egozcue, J.: The Chromosomes of the Lesser Bushbaby (Galago senegalensis)

and the Greater Bushbaby (Galago crassícaudatus) 236

Eitzman, D. V.: Immunoglobulin Levels in the Macaca mulatto

Epple, Gisela: Maintenance, Breeding, and Development of Marmoset Monkeys

(Callithricidae) in Captivity 56

Fitz-Gerald, F. L.; Barfield, M. A. and Grubbs, Patricia A.: Food Prefer

ences in Lowland Gorillas 209

Freedman, L.: vide Booth, S. N.

Gauthier-Hion, A.: L'organisation sociale d'une bande de Talapoins (Miopí-

thecus talapoín) dans le Nord-Est du Gabon 116

Grubbs, Patricia A.: vide Fitz-Gerald, F. L.

Hall, D. E.: vide Capel-Edwards, K.

Hershkovitz, P.: Notes on Tertiary Platyrrhine Monkeys and Description of a

New Genus from the Late Miocene of Colombia

1

Hill, W. C. O. and Sabater Pi, J.: Notes on Two Anomalies in Mandrills (Man-

drïllus sphinx Linn.) 290

Hobson, B. M.: Excretion of Gonadotrophin by the Pregnant Baboon (Papio

cynocephalus) $\quad 111$

Hofer, H. 0.: The Glandula Apicis Linguae in Pan troglodytes. A Preliminary

Note 38

Huser, H.-J.: vide Beard, M. E. J.

Hutchinson, T. C.: Vaginal Cytology and Reproduction in the Squirrel Monkey

(Saimiri scíureus) 212

Jolly, Alison: vide Klopfer, P. H.

Kanagasuntheram, R.; Krishnamurti, A. and Ahmed, M.: Nerve Termina

tions in the Digital Skin of the Hand in Some Lorisoids 42

Klopfer, P. H. and Jolly, Alison: The Stability of Territorial Boundaries in a

Lemur Troop 199

Krishnamurti, A.: vide Kanagasuntheram, R.

Leutenegger, W.: Beziehungen zwischen der Neugeborenengrösse und dem

Sexualdimorphismus am Becken bei simischen Primaten 224

Menzel, E. W., Jr.; Davenport, R. K. and Rogers, Ch. M.: The Development

of Tool Using in Wild-Born and Restriction-Reared Chimpanzees . . 273 Perkins, E. M.: vide

Egozcue, J. Poirier, F. E.: Dominance Structure of the Nilgiri Langur (Presbytis johnii)

of South India 161

Richard, Alison : A Comparative Study of the Activity Patterns and Behavior

of Alouatta villosa and At $\beta$ les geoffroyí

241

Rogers, Ch. M.: vide Menzel, E. W., Jr. 
Rowell, T. E. and Chalmers, N. R.: Reproductive Cycles of the Mangabey Cercocebus albigena 264

Saayman, G. S.: The Menstrual Cycle and Sexual Behaviour in a Troop of Free Ranging Chacma Baboons (Papio ursínus)

81

Sabater Pi, J.: vide Hill, W. C. 0. 